\title{
A novel methodology for large-scale daily assessment of the direct radiative forcing of smoke aerosols
}

\author{
E. T. Sena and P. Artaxo \\ Institute of Physics, University of São Paulo, São Paulo, Brazil \\ Correspondence to: E. T. Sena (elisats@if.usp.br)
}

Received: 8 October 2014 - Published in Atmos. Chem. Phys. Discuss.: 15 December 2014

Revised: 22 April 2015 - Accepted: 25 April 2015 - Published: 20 May 2015

\begin{abstract}
A new methodology was developed for obtaining daily retrievals of the direct radiative forcing of aerosols (24h-DARF) at the top of the atmosphere (TOA) using satellite remote sensing. Simultaneous CERES (Clouds and Earth's Radiant Energy System) shortwave flux at the top of the atmosphere and MODIS (Moderate Resolution Spectroradiometer) aerosol optical depth (AOD) retrievals were used. To analyse the impact of forest smoke on the radiation balance, this methodology was applied over the Amazonia during the peak of the biomass burning season from 2000 to 2009.

To assess the spatial distribution of the DARF, background smoke-free scenes were selected. The fluxes at the TOA under clean conditions $\left(F_{\mathrm{cl}}\right)$ were estimated as a function of the illumination geometry $\left(\theta_{0}\right)$ for each $0.5^{\circ} \times 0.5^{\circ}$ grid cell. The instantaneous DARF was obtained as the difference between the clean $\left(F_{\mathrm{cl}}\left(\theta_{0}\right)\right)$ and the polluted flux at the TOA measured by CERES in each cell $\left(F_{\text {pol }}\left(\theta_{0}\right)\right)$. The radiative transfer code SBDART (Santa Barbara DISORT Radiative Transfer model) was used to expand instantaneous DARFs to $24 \mathrm{~h}$ averages.

This new methodology was applied to assess the DARF both at high temporal resolution and over a large area in Amazonia. The spatial distribution shows that the mean 24h-DARF can be as high as $-30 \mathrm{~W} \mathrm{~m}^{-2}$ over some regions. The temporal variability of the 24h-DARF along the biomass burning season was also studied and showed large intraseasonal and interannual variability. We showed that our methodology considerably reduces statistical sources of uncertainties in the estimate of the DARF, when compared to previous approaches. DARF assessments using the new methodology agree well with ground-based measurements and radiative transfer models. This demonstrates the robust-
\end{abstract}

ness of the new proposed methodology for assessing the radiative forcing for biomass burning aerosols. To our knowledge, this is the first time that satellite remote sensing assessments of the DARF have been compared with ground-based DARF estimates.

\section{Introduction}

The Amazonia is the largest tropical rainforest of the world, occupying an area of more than 6.6 million $\mathrm{km}^{2}$ in South America. This large ecosystem plays a crucial role in regulating global and regional climate and the hydrological cycle, powering global atmospheric circulation, transporting heat and moisture to continental areas (Davidson and Artaxo, 2004; Artaxo et al., 2013). In the last decades, anthropogenic activities, such as deforestation for agricultural and urban expansion, have highly disturbed this environment (Betts et al., 2008; Bowman et al., 2009; Davidson et al., 2012). During the wet season, the Amazon Basin is one of the few continental places of the world where we can observe pristine conditions (Andreae, 2007). The population of aerosols during the wet season is dominated by primary biogenic coarse-mode particles (Martin et al., 2010), and presents typical concentration of about 300 particles per $\mathrm{cm}^{3}$ (Artaxo et al., 2002). This scenario changes dramatically during the dry season, with particle concentration reaching around 20000 particles per $\mathrm{cm}^{3}$ due to biomass burning emissions (Holben et al., 1996; Echalar et al., 1998; Andreae et al., 2002; Artaxo et al., 2009). This strong increase in aerosol concentration is accompanied by a significant modification in particle size distribution, since most of the particles emitted during burning 
events belong to the fine mode (Dubovik et al., 2002; Eck et al., 2003; Schafer et al., 2008).

Aerosol particles can modify the Earth's radiative balance in two ways: (i) directly, by interacting with solar radiation, through scattering and absorption processes (e.g. Charlson et al., 1992; Chylek and Wong, 1995), and (ii) indirectly, by modifying the microphysical structure of clouds, such as droplet size distribution and cloud albedo (e.g. Twomey, 1977; Coakley et al., 1987; Albrecht, 1989; Andreae et al., 2004; Koren et al., 2008). These effects depend on the concentration and on the horizontal and vertical distributions of particles in the atmosphere, on their optical properties, such as single-scattering albedo, size distribution, phase function, hygroscopicity, and on the surface reflectance properties of the underlying region (e.g. Haywood and Boucher, 2000; Yu et al., 2006). In particular, biomass burning aerosols play an important role in modifying the radiative energy balance of the affected region because fine-mode particles interact efficiently with solar radiation (Liou, 2002).

The direct aerosol radiative forcing (DARF) in Amazonia was previously assessed using radiative transfer models coupled with ground-based remote sensing measurements (Procopio et al., 2004) or on-site field campaigns (Ross et al., 1998). Although these approaches may provide detailed insight about a specific burning event, they are limited in space (in the case of ground-based studies) or in time (in the case of intensive field campaigns). As satellite remote sensing provides high spatial coverage it has been used to assess the large-scale DARF. An interesting technique used CERES (Clouds and Earth's Radiant Energy System) flux at the top of the atmosphere (TOA) combined with MODIS (Moderate Resolution Spectroradiometer) or MISR (Multi-angle Imaging Spectroradiometer) aerosol optical depth (AOD) to assess the mean DARF over Amazonia during the biomass burning season and analyse its spatial variability (Patadia et al., 2008; Sena et al., 2013). This technique (CERES + MODIS) has also been widely applied to evaluate the mean DARF over a time period (usually 2-3 months) in several other regions (e.g. Zhang et al., 2005; Christopher, 2011; Feng and Christopher, 2014; Sundström et al., 2015). Although these studies focused on averages are useful, they lack the high temporal resolution needed to observe important details on the changes of the radiative balance due to the short residence time of aerosols in the atmosphere. During the dry season, aerosol residence time within the boundary layer is estimated to be about 4 to 6 days (Freitas et al., 2005; Edwards et al., 2006). Also, biomass burning aerosols can be transported over great distances away from their sources (Andreae et al., 2001; Longo et al., 2009), depending on the prevalent dynamics in the studied area. Due to their short lifetime and to the dynamics of transport of these particles, aerosols present highly inhomogeneous spatial and temporal distributions. With that in mind, we developed a methodology for calculating the smoke DARF in Amazonia with higher spatial and temporal resolution than previous assess- ments $\left(0.5^{\circ} \times 0.5^{\circ}\right.$ and 1 day, respectively) using satellite remote sensing. As opposed to previous studies, that consider the total effect of aerosols (both from background and polluted conditions) on the radiative budget, this study focused on assessing the anthropogenic DARF only. This can also be regarded as an improvement over previous methodologies, since aerosol-free conditions cannot be observed in the atmosphere.

The main goals of this work were:

1. to introduce a new methodology to assess the daily direct radiative forcing of biomass burning aerosols over a large scale of Amazonia using satellite remote sensing (Sect. 2);

2. to analyse the intraseasonal and interannual variability of the daily average DARF as well as its mean daily spatial distribution pattern over Amazonia (Sects. 3.1 and 3.2);

3. to validate the calculated DARF obtained by applying this new methodology with ground-based sensors, as well as radiative transfer DARF calculations (Sect. 4).

We also believe that this methodology could be easily applied to study the 24h-DARF in other regions of the world, impacted by biomass burning or even urban pollution.

\section{Data and methods}

In this work, combined CERES shortwave TOA flux and MODIS aerosol optical depth (AOD) at $550 \mathrm{~nm}$ were used to assess the direct radiative forcing of biomass burning aerosols over the Amazon Basin for cloud-free conditions. These both instruments are aboard NASA's Terra and Aqua satellites.

CERES sensors are passive scanning radiometers that measure the upward radiance in three broadband channels: (i) between 0.3 to $5.0 \mu \mathrm{m}$, to measure the shortwave radiation reflected in the solar spectrum; (ii) between 8 and $12 \mu \mathrm{m}$, to measure the thermal radiation emitted by the Earth in the atmospheric window spectral region, and (iii) between 0.3 and $200 \mu \mathrm{m}$ to measure the total radiation spectrum emerging at the TOA (Wielicki et al., 1996). Radiance measurements are converted into broadband radiative fluxes through the use of angular distribution models (ADMs) (Loeb et al., 2005).

MODIS measures the radiance at the TOA in 36 narrow spectral bands between 0.4 and $14.4 \mu \mathrm{m}$ (Salomonson et al., 1989). Among its various applications, MODIS observations have been widely used to monitor land surface, oceans and atmosphere properties and to provide information about cloud and aerosol optical properties, their spatial and temporal variations, and the interaction between aerosols and clouds (King et al., 1992).

CERES Single Scanner Footprint (CERES-SSF) product provides simultaneous retrievals of the upward flux at the 
TOA derived by CERES on three broadband channels, and properties of aerosols and clouds reported by MODIS. In this product, MOD04 aerosol and cloud properties, that are originally reported with a $10 \mathrm{~km}$ spatial resolution, are reprojected to CERES $20 \mathrm{~km}$ resolution (Smith, 1994). Over land, MODIS's AOD uncertainty is estimated as: $\sigma_{\text {land }}=$ $\pm 0.05 \pm 0.15 \mathrm{AOD}_{550 \mathrm{~nm}}$ (Remer et al., 2005).

For the development of the new methodology presented here, we used CERES-SSF Edition 3A shortwave flux retrievals at the TOA from Terra satellite over the Amazon Basin from 1 July to 31 October from 2000 to 2009. The studied area was limited between the coordinates $3^{\circ} \mathrm{N}-20^{\circ} \mathrm{S}$, $45-65^{\circ} \mathrm{W}$ and $3^{\circ} \mathrm{N}-11^{\circ} \mathrm{S}, 65-74^{\circ} \mathrm{W}$. Pixels with $1 \mathrm{~km}$ resolution MODIS cloud fraction above $0.5 \%$ and with a clear area in the MODIS $250 \mathrm{~m}$ resolution lower than $99.9 \%$ were removed. To limit distortions we removed from our analysis pixels that presented view and solar zenith angles greater than $60^{\circ}$. The DARF was calculated with a $0.5^{\circ} \times 0.5^{\circ}$ latitude/longitude spatial resolution, according to the methodology described in the next section.

\subsection{Evaluation of the daily direct RF of biomass burning aerosols}

The direct radiative forcing of aerosols (DARF) can be defined as the difference between the upward radiation flux at the TOA measured in background $\left(F_{\mathrm{cl}}\right)$ and polluted $\left(F_{\mathrm{pol}}\right)$ conditions:

$\mathrm{DARF}=F_{\mathrm{cl}}-F_{\mathrm{pol}}$.

For each scene observed by CERES, $F_{\mathrm{pol}}$ can be directly obtained from the mean flux at the TOA for each $0.5^{\circ} \times 0.5^{\circ}$ grid cell. To calculate the instantaneous DARF, we need to estimate what would be the flux at the TOA for background conditions $\left(F_{\mathrm{cl}}\right)$ for the same illumination geometry of the polluted scene. To perform this estimate, scenes that presented aerosol optical depth (AOD) smaller than 0.1 were selected, and considered as background scenes. This threshold was selected by analysing AERONET's AOD during the wet season. For each cell, the flux at the TOA observed for background scenes $\left(F_{\mathrm{cl}}\right)$ during the 40 months studied period was plotted against the cosine of the solar zenith angle $\left(\cos \left(\theta_{0}\right)\right)$. An example of this plot, for the grid cell centred at latitude $8.75^{\circ} \mathrm{S}$ and longitude $53.75^{\circ} \mathrm{W}$, is shown in Fig. 1 . A correlation coefficient of 0.94 between $F_{\mathrm{cl}}$ and $\cos \left(\theta_{0}\right)$ was observed for the data points within this cell indicating the adequacy of the linear approximation. It is worth emphasizing that this example is not a best-case scenario. In fact, more than $80 \%$ of the cases analysed showed a correlation larger than 0.90 between $F_{\mathrm{cl}}$ and $\cos \left(\theta_{0}\right)$.

The solar zenith angle varied from about 10 to $52^{\circ}$ at Terra satellite passage time over the Amazonia during the study period. For this solar zenith angle range, $F_{\mathrm{cl}}$ varies linearly with $\cos \left(\theta_{0}\right)$. By adjusting a linear fit to the data points within each cell we can calculate $F_{\mathrm{cl}}\left(\theta_{0}\right)$ for any illumination geometry,

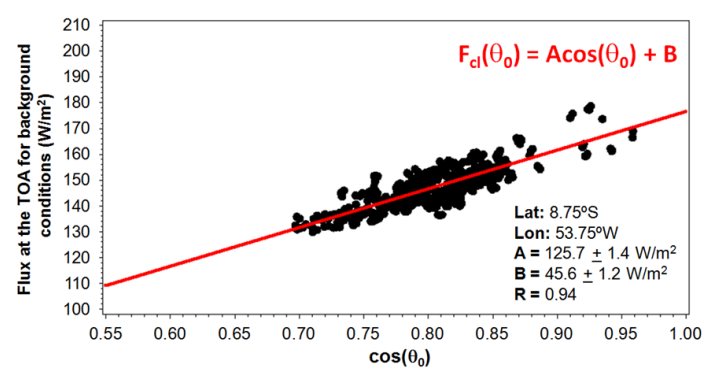

Figure 1. Example of the procedure used to obtain the flux at the top of the atmosphere (TOA) for background conditions $\left(F_{\mathrm{cl}}\right)$ as a function of the solar zenith angle $\left(\theta_{0}\right)$ for a $0.5^{\circ} \times 0.5^{\circ}$ cell located in the Amazon Basin. In this example, 4 months worth of data over the grid cell were used, from July to October 2005.

according to

$F_{\mathrm{cl}}\left(\theta_{0}\right)=A \cos \left(\theta_{0}\right)+B$,

where $A$ and $B$ correspond to the slope and the intercept of the linear fit, respectively.

To assess the instantaneous DARF, the mean solar zenith angle within each cell during the satellite passage time was identified for every polluted scene. For each cell, the instantaneous DARF was evaluated as the difference between $F_{\mathrm{cl}}\left(\theta_{0}\right)$ and the mean flux at the TOA retrieved by CERES in polluted conditions $\left(F_{\mathrm{pol}}\left(\theta_{0}\right)\right)$, as previously stated in Eq. (1). The uncertainty of the DARF in each cell $\left(\sigma_{\mathrm{DARF}}\right)$, was computed using error propagation, according to

$\sigma_{\mathrm{DARF}}^{2}=\sigma_{A}^{2} \cos ^{2}\left(\theta_{0}\right)+\sigma_{B}^{2}+2 \operatorname{cov}(A, B) \cos \left(\theta_{0}\right)+\sigma_{F_{\mathrm{pol}}}^{2}$,

where $\sigma_{A}, \sigma_{B}$ and $\operatorname{cov}(A, B)$ are the uncertainty of the slope, intercept and the covariance between the slope and the intercept, respectively; $\sigma_{F_{\mathrm{pol}}}$ is the uncertainty of the flux in each cell for the polluted condition.

\subsection{Correction of the DARF according to empirical ADMs}

As already discussed, to convert CERES radiance measurements to radiative flux at the TOA it is necessary to define the angular distribution models (ADMs) for different scenes (Loeb et al., 2005). In a recent work, Patadia et al. (2011) pointed out that the angular distribution models currently used by CERES team to derive shortwave fluxes at the TOA over land in cloud-free conditions do not take into account aerosol properties in the observed scene. This can result in large errors in the shortwave fluxes derived by this sensor for areas with high concentrations of aerosols, such as the Amazonia during the biomass burning season. To estimate the impact of the anisotropy caused by high aerosol loading on the flux at the TOA, Patadia et al. (2011) developed a methodology to obtain new empirical angular distribution models for the Amazon Basin region during the dry season. The authors 
used radiance measurements obtained by CERES shortwave channel over the Amazonia for different view and solar illumination geometries between 2000 and 2008. In a later work they assessed the difference between the DARF evaluated using both CERES ADMs and their new empirical ADMs (Patadia and Christopher, 2014). They found that, on average, CERES DARF relates to the corrected DARF calculated with their empirical ADMs, according to the following equation:

$\mathrm{DARF}_{\text {corrected }}=\mathrm{DARF}-17.12 \mathrm{AOD}-0.93$.

The correction proposed by Patadia and Christopher (2014) was applied to the CERES-MODIS DARF estimates introduced in the previous section.

A discrete-ordinate radiative transfer (DISORT) code (Stamnes et al., 1988) was used to expand the instantaneous radiative forcing, calculated for the satellite passage time, to $24 \mathrm{~h}$ averages. MODIS BRDF/Albedo Model (MCD43B1) retrievals (Schaaf et al., 2002) over the studied area were used to develop the surface albedo models used in the radiative transfer calculations. Aerosol optical properties retrieved by the AERONET (Aerosol Robotic Network) ground-based sun photometers (Dubovik and King, 2000) located in the Amazonia during the dry season were also used in this computation. For a detailed description of the methodology used to perform this expansion please refer to Sena et al. (2013).

\section{Results and discussions}

In this section we present and explore the main results obtained by applying the methodology introduced in Sect. 2.1 to assess the DARF. Some examples of the spatial distribution and the temporal variability of the 24h-DARF along the biomass burning season are shown and discussed. In Sect. 3.3, the average of the DARF during the biomass burning season of each year is computed and compared with previous DARF results.

\subsection{Examples of the spatial distribution of the 24h-DARF}

In Brazil, most fires occur on the southern and eastern borders of the Amazon Basin, in a region known as the "arc of deforestation" (Malhi et al., 2008; Morton et al., 2008). During the dry season low-level Easterly winds dominate the atmospheric circulation over central South America (Nobre et al., 1998). Due to this dynamical feature, smoke particles are transported towards the forest and the Andes mountain range, where eventually wind direction changes (Freitas et al., 2009). Biomass burning aerosols can be transported over long distances away from their sources (Andreae et al., 2001; Freitas et al., 2005; Longo et al., 2009; Mishra et al., 2015) and cover large areas of up to millions of $\mathrm{km}^{2}$ (Prins et al., 1998). Aerosol transport during the biomass burning season
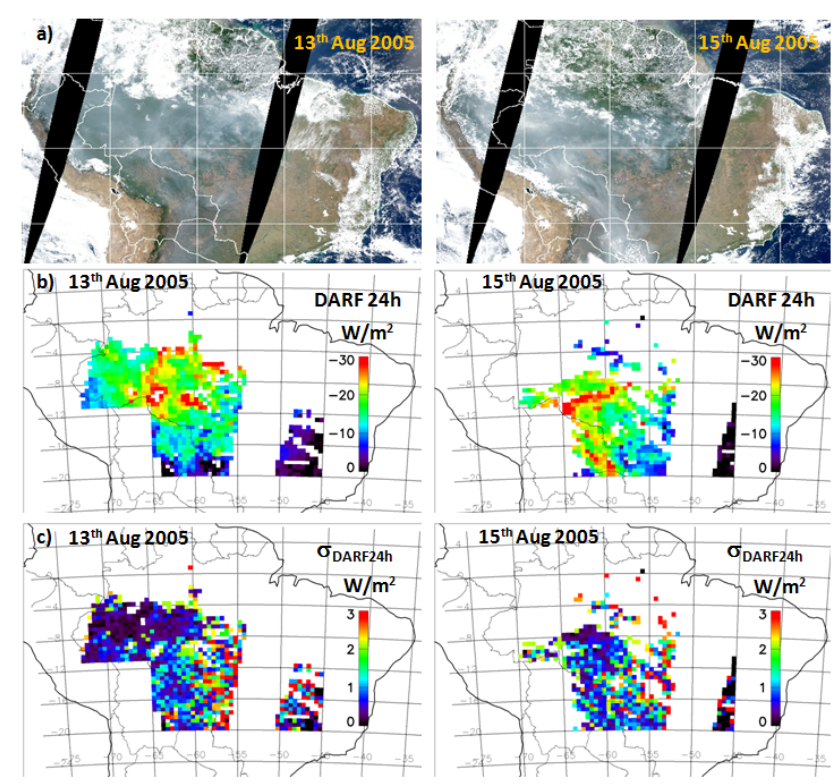

Figure 2. (a) Examples of composite MODIS RGB (red, green, blue) images over the Amazonia, (b) mean daily spatial distributions of the direct aerosol radiative forcing of aerosols (24h-DARF), (c) and their uncertainties for 13 August 2005 (left) and $15 \mathrm{Au}$ gust 2005 (right).

can significantly modify the spatial distribution of the DARF from one day to another. Two examples of the spatial distribution of the 24h-DARF, for 13 and 15 August 2005, are shown in Fig. 2, with their respective uncertainties. Composite images from MODIS's red, blue and green spectral channels are also shown in this figure.

Figure 2 shows that, on 13 August 2005, the smoke plume covers a large area of the Brazilian Amazonia, between 4 and $12^{\circ} \mathrm{S}$ and 55 and $70^{\circ} \mathrm{W}$. The 24h-DARF over the area was particularly high for that day, varying from about -30 to $-15 \mathrm{~W} \mathrm{~m}^{-2}$. On 15 August 2005, we note that the smoke plume has moved southeast, following the Andes mountain range line, strongly impacting the southern Amazonia, western Bolivia and northern Paraguay. The area located between 8 and $20^{\circ} \mathrm{S}$ and 57 and $65^{\circ} \mathrm{W}$ showed the highest $24 \mathrm{~h}$-DARF values for that day, also ranging from -30 to $-15 \mathrm{~W} \mathrm{~m}^{-2}$. The $24 \mathrm{~h}-\mathrm{DARF}$ showed in Fig. $2 \mathrm{~b}$ was, on average, $-14.3 \pm 0.3 \mathrm{~W} \mathrm{~m}^{-2}$ on 13 August and $-15.6 \pm 0.3 \mathrm{~W} \mathrm{~m}^{-2}$ on 15 August. These results clearly show the importance of wind circulation in the transport of aerosol plumes and how atmospheric dynamics may influence the shortwave radiative balance of the region.

\subsection{Temporal variability of the DARF along the biomass burning season}

Due to the short lifetime of aerosols in the atmosphere, the DARF may vary largely during the 2 months of the biomass burning season. To analyse this temporal variability, the aver- 


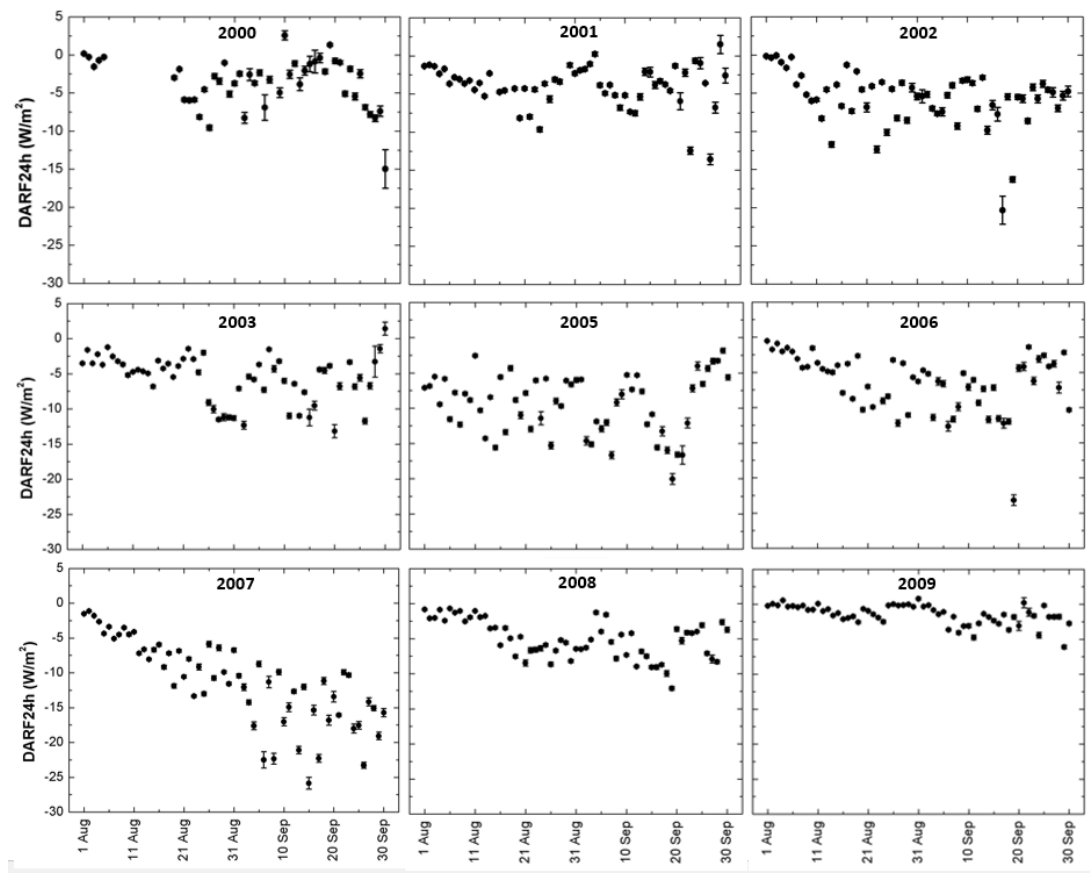

Figure 3. Temporal variability of the direct radiative forcing of aerosols (24h-DARF) along the biomass burning seasons of 2000 to 2009.

age of the 24h-DARF over the study area was calculated for each day of the year. Time series of the mean daily DARF during the biomass burning season from 2000 to 2009 are illustrated in Fig. 3. Due to a problem in CERES-SSF data processing, the year 2004 presents a high amount of missing values for aerosol and cloud properties in its database. Therefore this year was not included in Fig. 3, nor in the forthcoming analysis.

Figure 3 shows that, besides its large interannual variability, the DARF also varies widely along the biomass burning season. Different temporal patterns along the biomass burning season are observed depending on the year. For example, for most of 2005's dry season, the DARF showed little variation, averaging around $-9 \pm 2 \mathrm{~W} \mathrm{~m}^{-2}$. On the other hand, in 2007, the DARF became gradually more negative, starting around $0 \mathrm{~W} \mathrm{~m}^{-2}$ in the beginning of August and reaching values of the order of $-25 \mathrm{~W} \mathrm{~m}^{-2}$ at the end of September. However, 2005 and 2007 both present similar mean 24hDARF during the burning season, as will be shown in the next section (Fig. 4). The DARF was also near-constant during the dry season of 2009. For most of the years, however, the temporal variation pattern during the biomass burning season was neither constant nor linear. In 2002 the DARF decreases in the beginning of the dry season and then saturates at about $-5 \mathrm{~W} \mathrm{~m}^{-2}$. In 2006 the DARF follows a similar pattern to that of 2002, saturating at about $-10 \mathrm{~W} \mathrm{~m}^{-2}$ and increasing once again in the end of September. For the remaining years $(2000,2001,2003$ and 2008) the seasonal variability of the DARF was more complex, with the DARF increasing/decreasing more than once during this 2-month period.
The interannual variability of the DARF can also be observed. The impact of smoke aerosols in the radiative balance of 2005 and 2007 was very pronounced, while the DARF was very close to zero during the whole biomass burning season of 2009. The high DARFs in 2005 and 2007 are associated with severe droughts that contributed to forest and savanna fires and high aerosol loadings in these years (Marengo et al., 2008; Ten Hoeve et al., 2012). On the other hand, the rainfall over the Amazonia in 2009 was extremely high (Satyamurty et al., 2013), which contributed to the decrease in the number of fire sources and the efficient removal of smoke aerosols from the atmosphere. These results indicate that rainfall patterns and the interannual variability of the DARF are likely related. Socio-economical changes, related to land-use and deforestation, can also affect aerosol loading (Davidson et al., 2012), and therefore contribute to the DARF variability.

The daily DARF variations from one day to another, shown in this figure, are mainly due to changes at the MODIS imaged area, which varies according to the satellite track. Due to its polar orbiting track, every day the scanned area slightly changes, finally repeating itself after about 16 days. Depending on Terra track, for some cases MODIS does not cover areas heavily impacted by smoke aerosols, and the mean 24h-DARF could be underestimated. Cloud cover can also change significantly in short periods of time (2-3 days), and this can strongly impact daily DARF retrievals. Furthermore, the daily DARF variation is also influenced by changes in fire source location and transport along the biomass burning season. 

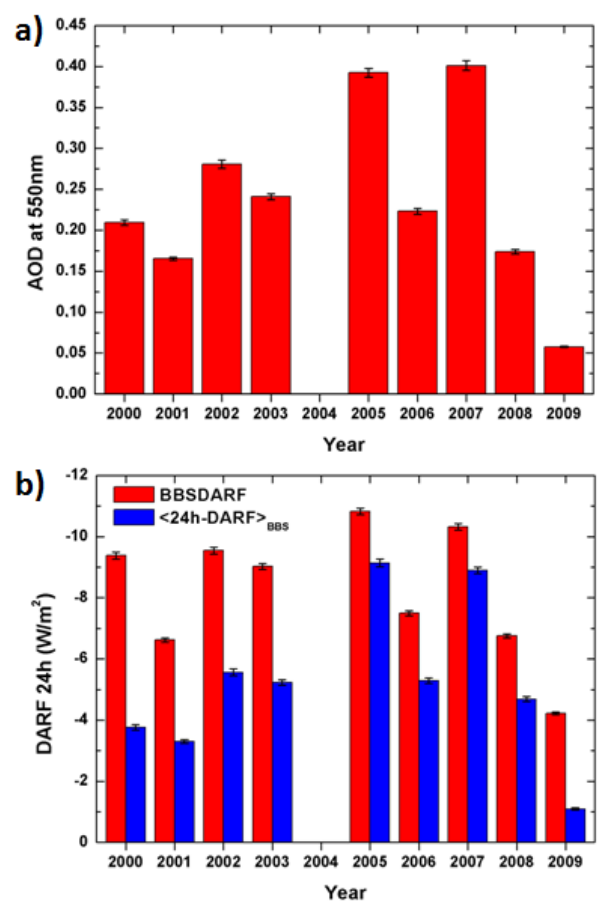

Figure 4. (a) MODIS mean aerosol optical depth at $550 \mathrm{~nm}$ over Amazonia during the dry season and (b) mean direct aerosol radiative forcing of aerosols (24h-DARF) during the peak of the biomass burning season (August to September) from 2000 to 2009 obtained by the methodology applied by Sena et al. (2013) (BBSDARF) and by the methodology proposed in this work $\left(\langle 24 \mathrm{~h}-\mathrm{DARF}\rangle_{\mathrm{BBS}}\right)$.

\subsection{Average of the DARF during the biomass burning season}

In previous studies (Patadia et al., 2008; Sena et al., 2013), the average of the direct radiative forcing of aerosols during the biomass burning season over the Amazonia was also calculated by using CERES and MODIS sensors. In those approaches, the average flux for clean conditions during the biomass burning season $\left(\mathrm{BBSF}_{\mathrm{cl}}\right)$ for each cell grid was estimated from the intercept of the regression between TOA fluxes and AOD retrievals from August to September. The mean DARF during the biomass burning season (BBSDARF) was then calculated by subtracting the mean flux at the TOA $\left(\mathrm{BBSF}_{\mathrm{pol}}\right)$ from the mean flux for clean conditions $\left(\mathrm{BBSF}_{\mathrm{cl}}\right)$ observed as averages during this 2-month study period. The DARF calculated using this methodology considers the total effect of aerosols. Since the flux for clean conditions $\left(F_{\mathrm{cl}}\right)$ is defined for $\mathrm{AOD}=0$, the effect of smoke aerosols cannot be isolated from the effect of background aerosols. Thus the total effect of aerosols from both background and polluted conditions are included in the BBSDARF.

The new methodology introduced here (Sect. 2.1), provides the 24h-DARF for each individual day, with a much higher temporal resolution than the one used in previous studies. Furthermore this new methodology considers a more realistic clean condition, by defining $F_{\mathrm{cl}}$ in the presence of background aerosols. Since background aerosols are always present in the atmosphere, the contribution of background aerosols to the radiative balance should not be considered as forcing in the strict sense. In fact, some authors define the contribution of background + polluted aerosols as the direct radiative effect instead of direct radiative forcing (e.g. Yu et al., 2006).

In this section we have compared the DARF obtained using the new methodology introduced in Sect. 2.2 with the seasonal DARF values calculated previously by Sena et al. (2013). For this comparison, the daily DARF, obtained in this work, was averaged between the months of August and September of each year ( $\left.\langle 24 \mathrm{~h}-\mathrm{DARF}\rangle_{\mathrm{BBS}}\right)$. To ensure that we make a fair comparison, the corrections proposed by Patadia and Christopher (2014), and used for the evaluation of the 24h-DARF in this paper (Sect. 2.2), were also applied a posteriori to the Sena et al. (2013) seasonal forcing (BBSDARF). Figure 4 shows the mean AOD at $550 \mathrm{~nm}$ during the biomass burning, and the comparison between $\langle 24 \mathrm{~h}-\mathrm{DARF}\rangle_{\mathrm{BBS}}$ and BBSDARF, calculated over the studied area, from 2000 to 2009. Once again, 2004 was excluded from the analysis, due to CERES-SSF database problems discussed in the previous section.

Figure 4 shows that the $\langle 24 \mathrm{~h}-\mathrm{DARF}\rangle_{\mathrm{BBS}}$ is always lower than the BBSDARF. The average of the BBSDARF for this 10-year period (2000 to 2009) is $-8.2 \pm 2.1 \mathrm{~W} \mathrm{~m}^{-2}$, while the 10-year average of the $\langle 24 \mathrm{~h}-\mathrm{DARF}\rangle_{\mathrm{BBS}}$ is $-5.2 \pm 2.6 \mathrm{~W} \mathrm{~m}^{-2}$. Two factors contribute to this difference: (i) different references were used at the assessment of the clean flux, $F_{\mathrm{cl}}$, in each methodology ( $\mathrm{AOD}=0$ vs. background conditions), and (ii) CERES-SSF product provides an older MOD04 collection before 2005, and this strongly affects BBSDARF retrievals. In the following paragraphs, these DARF differences and their sources will be further explored.

SBDART (Santa Barbara DISORT Radiative Transfer model) (Richiazzi et al., 1998) calculations suggest that the contribution of background aerosols at $\mathrm{AOD}=0.1$ to the 24h-DARF over the Amazonia is about $-2 \mathrm{~W} \mathrm{~m}^{-2}$. Hence, the contribution of background aerosols may explain the magnitude of the differences in the radiative forcings obtained from 2005 on, but not before that year. Part of the DARF differences observed from 2000 to 2003 are very likely associated with the aerosol optical properties contained in CERES-SSF product, Edition 3A, used both in this work and by Sena et al. (2013). This product provides aerosol optical properties calculated using MODIS aerosol algorithm MOD04 collection 4 until mid-2005, and MOD04 collection 5 after that date. A major difference between aerosol optical depths obtained by these two collections is due to the fact that collection 4 does not allow negative values of AOD, while for collection 5, the lowest limit for the AOD is -0.05 , to account for the uncertainty of the retrieved AOD. Therefore, for low aerosol loading, when AOD from 
MOD04 collection 4 is projected to CERES lower resolution, it may be overestimated, since negative AOD values were removed from the average. Thus, when applying the methodology used by Patadia et al. (2008) and Sena et al. (2013), to CERES-SSF data that contained MOD04 collection 4 AOD, the $\mathrm{BBSF}_{\mathrm{cl}}$ is underestimated and, therefore, the BBSDARF is overestimated (Fig. 5). This explains the differences between both DARF evaluations observed in Fig. 4.

The solar zenith angle strongly influences the upward flux at the TOA $\left(F_{\mathrm{TOA}}\right)$. CERES fluxes retrievals obtained over the same surface, for the same aerosol loading and same atmospheric conditions, and at different illumination geometry will present different $F_{\text {TOA }}$. In the previous methodology used in Sena et al. (2013), 2 months of data were used to estimate the BBSDARF through the linear fit of $F_{\mathrm{TOA}}$ by AOD. Thus, flux measurements performed on different days and at different times (and therefore different solar zenith angles) contributed to increase the dispersion of the points on the $y$-axis, increasing the uncertainty of BBSDARF. In the new methodology, the DARF is obtained as a function of the solar zenith angle, which eliminates the noise caused by solar zenith angle variations, observed in previous studies. This was another important improvement of the methodology proposed in this work over the previously used methodology.

It is also important to emphasize that both methodologies are applied only in cloud-free conditions. MODIS Level 3 cloud fraction retrievals indicate that during the study period (August to September) the cloud fraction over Amazonia is on average about $47 \%$, during Terra morning passage (about 10:30 a.m. LT), increasing to about $56 \%$, during the afternoon (Aqua passage time is about 1:30 p.m.). Therefore, the mean $\langle 24 \mathrm{~h}-\mathrm{DARF}\rangle_{\mathrm{BBS}}$ over the whole study area weighted by cloud cover is about $-2.6 \mathrm{~W} \mathrm{~m}^{-2}$.

The mean correlation between the AOD $550 \mathrm{~nm}$ and the $\langle 24 \mathrm{~h}-\mathrm{DARF}\rangle_{\mathrm{BBS}}$ from 2000 to 2009 is $-0.86 \pm 0.03$, which is better than the mean correlation between the AOD and BBSDARF previously obtained, of $-0.75 \pm 0.05$. This is another indication that the new daily methodology proposed here is more robust to evaluate the DARF than the seasonal averaged methodology used in previous studies.

\section{Comparison between satellite and ground-based direct radiative forcing}

The methodology proposed in this work uses upward TOA flux estimates from CERES-MODIS sensors aboard Terra for evaluating the DARF over the Amazonia and Cerrado regions. As CERES relies on angular distribution models (ADMs) for estimating the upward flux at the TOA, it is very hard to validate those flux retrievals. Up to date, the validation of these TOA fluxes has only been made indirectly, by comparing TOA fluxes retrieved by broadband radiometers aboard different satellites (Loeb et al., 2007). As previously discussed, the use of different ADMs to convert

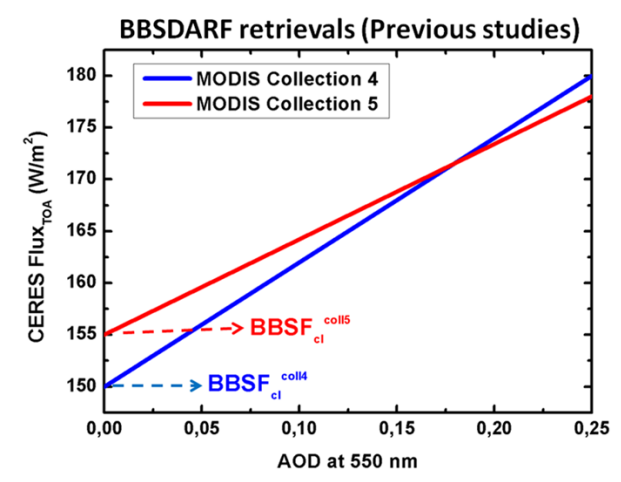

Figure 5. Schematic illustration of the differences in the linear fits of CERES flux at the top of the atmosphere (TOA) and MODIS collection 4 and collection 5 aerosol optical depth (AOD) at $550 \mathrm{~nm}$. No real data were used in this figure.

broadband radiance measurements into flux may introduce large differences in the calculated DARF using satellite remote sensors (Patadia and Christopher, 2014). We have applied a correction to the DARF based on Patadia et al. (2011) empirical ADMs that accounts for the influence of aerosols in the anisotropy of scattered radiation. Nevertheless, those new angular distribution functions are also not validated and, since there are no instruments that directly measure the upward flux at the TOA, it is not possible to truly validate either CERES ADMs or Patadia's empirical ADMs.

As an attempt to indirectly validate the DARF results obtained here, we compared the DARF, calculated in this work, with both ground-based measurements and radiative transfer forcing estimates. In Sect. 4.1 we analysed the intercomparison between CERES-MODIS forcings, with those reported by AERONET's (AErosol RObotic NETwork) radiative forcing product. In Sect. 4.2, CERES-MODIS forcings were compared with radiative forcing evaluations computed using SBDART (Santa Barbara DISORT Atmospheric Radiative Transfer model) radiative transfer code (Richiazzi et al., 1998).

\subsection{Intercomparison between CERES-MODIS and AERONET 24h-DARF}

AERONET is one of the most successful ground-based global networks of sun/sky radiometers for studying and monitoring aerosol physical properties around the world (Holben et al., 1998). Direct and almucantar measurements from AERONET radiometers are used to retrieve AOD and several column-averaged aerosol optical and physical properties in different spectral bands. Extinction measurements on the spectral channel centred at $940 \mathrm{~nm}$ are used to assess column water vapour (Halthore et al., 1997). In its inversion product version 2.0, AERONET provides cloud-free sky DARF estimates evaluated using the radiative transfer code GAME (Global Atmospheric Model) (Dubuisson et al., 
1996). The aerosol and surface models used in GAME are based on mean column averaged aerosol optical properties retrieved by AERONET's inversion algorithm (Dubovik and King, 2000) and surface properties retrieved by MODIS bidirectional reflectance product (Lucht et al., 2000; Schaaf et al., 2002), respectively.

The CERES-MODIS DARF, calculated according to the methodology described in Sect. 2.1, was compared with the DARF reported by AERONET's inversion product. For this, we selected forcing results, located within $\pm 25 \mathrm{~km}$ of the AERONET sites that operated in the Amazonia during the study period (Abracos Hill, Alta Floresta, Balbina, Belterra, Cuiabá, Ji-Paraná and Rio Branco). AERONET's almucantar measurements, needed to calculate the radiative forcing, are made only when the solar zenith angle is larger than $50^{\circ}$. However, during the dry season, at the time Terra overpasses the study region (around 10:30LT), the solar zenith angle is on average around $33^{\circ}$. For this reason, there were no coincident instantaneous DARF retrievals from CERESMODIS radiometers and AERONET sun photometers. To compare the results, the instantaneous DARF, obtained by both CERES-MODIS and AERONET, were expanded to $24 \mathrm{~h}$ average DARF using the methodology described in Sena et al. (2013). A comparison between the 24h-DARF at the TOA obtained using AERONET and CERES-MODIS is shown in Fig. 6.

By applying a linear fit to the data points of Fig. 6, we see that the 24h-DARF derived from CERES-MODIS relates with the 24h-DARF reported by AERONET through the following equation:

$$
\begin{aligned}
\mathrm{DARF}_{\text {CERES-MODIS }}^{24 \mathrm{~h}} & =(1.07 \pm 0.04) \mathrm{DARF}_{\mathrm{AERONET}}^{24 \mathrm{~h}} \\
& -(0.0 \pm 0.6) .
\end{aligned}
$$

According to this equation, the agreement between CERESMODIS and AERONET 24h-DARF is acceptable within the standard deviations of the fitted parameters. This is a remarkable result, since the 24h-DARF retrievals, shown in Fig. 6, were obtained by applying completely different methodologies, and using different instruments. AERONET sun photometers are at the surface and CERES-MODIS instruments are at $705 \mathrm{~km}$ aboard Terra satellite both looking at the atmospheric column. Besides that, as explained above, the instantaneous observations that were used to calculate the $24 \mathrm{~h}$ DARF, compared in our analysis, were performed at different hours of the day. All those differences contribute to the dispersion of about $5 \mathrm{~W} \mathrm{~m}^{-2}$ around the adjusted line. The uncertainties involved in the surface and aerosol optical models used in GAME's radiative transfer code to calculate AERONET's DARF can also contribute to this dispersion. These results indicate a high agreement between the $24 \mathrm{~h}$ DARF obtained by these two independent procedures.

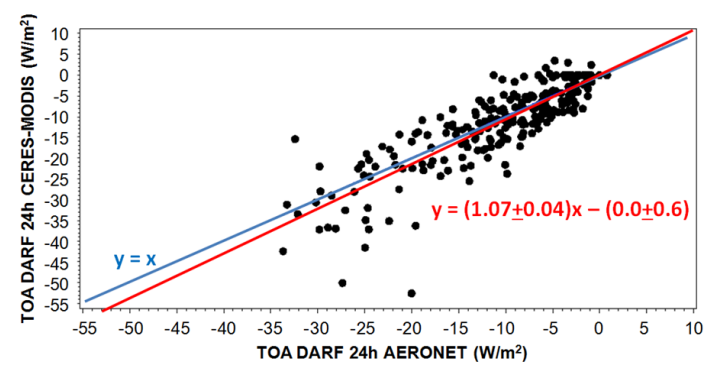

Figure 6. Intercomparison between the mean daily direct radiative forcing (24h-DARF) at the top of the atmosphere (TOA) evaluated using CERES-MODIS and by AERONET inversion product.

\subsection{Intercomparison between CERES-MODIS and SBDART instantaneous DARF}

It is also important to intercompare satellite remote sensing retrievals with ground-based measurements. In order to properly do that, we compare CERES-MODIS data at the TOA with SolRad-NET (Solar Radiation Network) pyranometers at the bottom of the atmosphere (BOA), using SBDART calculations to link BOA to TOA. To formulate the surface models used in SBDART, we selected $50 \mathrm{~km} \times 50 \mathrm{~km}$ areas centred at the AERONET stations listed in Sect. 4.1. For each selected area, the spectral surface albedo was obtained from the linear interpolation of MODIS MCD43B1 surface albedo retrievals in seven wavelengths (Lucht et al., 2000; Schaaf et al., 2002). The aerosol models used in these simulations were built using daily averages of intrinsic aerosol optical properties retrieved by AERONET. The aerosol optical depth and column water vapour measured by AERONET sun photometers within $\pm 1 / 2 \mathrm{~h}$ of Terra's timepass over each site were also used as inputs in the radiative transfer code. The shortwave downward flux at the surface and the DARF at the TOA were computed by SBDART and compared with groundbased sensors solar flux measurements and with CERESMODIS DARF, respectively.

Figure 7 shows the comparison between the downward flux at the surface $\left(F_{\downarrow \text { BOA }}\right)$ calculated by SBDART between 0.3 and $2.8 \mu \mathrm{m}$ and coincident solar flux measurements at the surface in the same spectral range from SolRad-NET pyranometers, that are collocated with AERONET sun photometers. A linear fit of the downward flux measured by the pyranometer at the surface $\left(F_{\mathrm{BOA}}^{\mathrm{PYRANOMETER}}\right)$ and calculated by $\operatorname{SBDART}\left(F_{\mathrm{BOA}}^{\mathrm{SBDART}}\right)$ indicate that these variables are related through the following equation:

$$
F_{\mathrm{BOA}}^{\mathrm{PYRANOMETER}}=(1.00 \pm 0.04) F_{\mathrm{BOA}}^{\mathrm{SBDART}}-(20 \pm 27) .
$$

Equation (6) shows that the agreement between calculated and measured BOA fluxes is acceptable within the standard deviations. The apparent mismatch of about $20 \mathrm{~W} \mathrm{~m}^{-2}$ between the calculated and measured values represents approximately $2.2 \%$ of the downward flux at the surface, and this is 


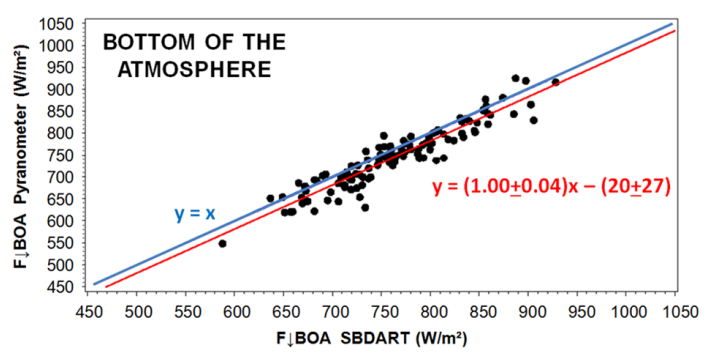

Figure 7. Intercomparison between the incoming flux in $\mathrm{W} \mathrm{m}^{-2}$ at the bottom of the atmosphere (BOA) measured by SolRad-NET pyranometers and modelled using AERONET and MODIS BRDF retrieved optical properties as inputs in SBDART.

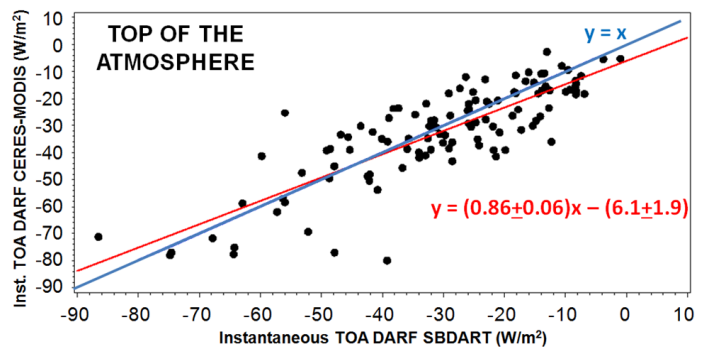

Figure 8. Intercomparison between the instantaneous direct aerosol radiative forcing (DARF) at the top of the atmosphere (TOA) evaluated using CERES-MODIS and modelled using AERONET and MODIS BRDF retrieved optical properties as inputs in SBDART.

close to the instrumental uncertainty of the pyranometer, reported as $2 \%$. These results show a good agreement between the downward irradiance at the surface, calculated using SBDART and SolRad-NET pyranometer measurements.

The intercomparison between the instantaneous TOA DARF obtained using CERES-MODIS and calculated using SBDART is shown in Fig. 8. The data points in this graph have a dispersion of about $10 \mathrm{~W} \mathrm{~m}^{-2}$ around the $1: 1$ line. A linear fit of the data plotted in Fig. 8 shows that the instantaneous TOA DARF obtained from CERES-MODIS and from SBDART relate through the following equation:

$$
\begin{aligned}
\text { DARF }_{\text {CERES-MODIS }} & =(0.86 \pm 0.06) \text { DARF }_{\text {SBDART }} \\
& -(6 \pm 2)
\end{aligned}
$$

Several issues in this comparison must be taken into account. First the upward flux is strongly influenced by the surface reflection. MODIS sensor presents low spectral resolution in the shortwave spectrum and this limits the surface albedo model used as input in SBDART. Secondly, the atmosphere has to be taken into account twice: on the downward and upward path. This amplifies any inaccuracy in the optical properties assumed in the SBDART calculations.

Small deviations in the estimates of aerosol singlescattering albedo can generate large differences in the forcing calculated by radiative transfer codes (Loeb and Su, 2010; Boucher et al., 2013). To assess the impact of the uncer-

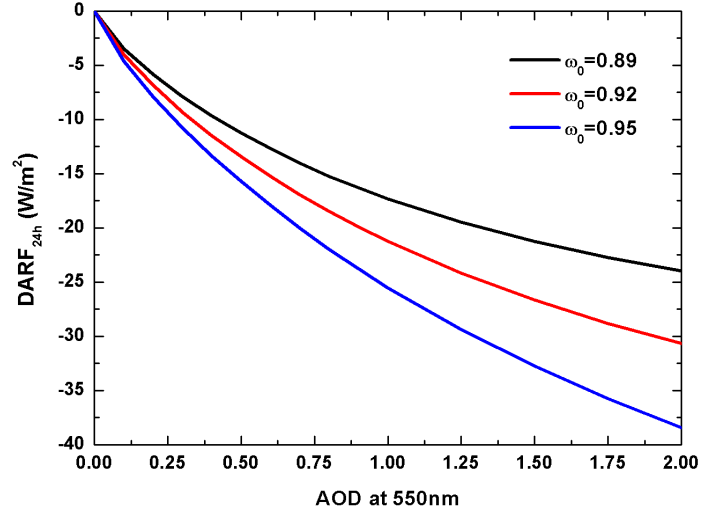

Figure 9. Direct radiative forcing of biomass burning aerosols (24hDARF) over the forest as a function of aerosol optical depth (AOD) at $550 \mathrm{~nm}$ and single-scattering albedo $\left(\omega_{0}\right)$ at $440 \mathrm{~nm}$ according to radiative transfer calculations.

tainties associated with different single-scattering albedo values, the 24h-DARF was computed in SBDART as a function of AOD at $550 \mathrm{~nm}$ for different values of single-scattering albedo at $440 \mathrm{~nm}\left(\omega_{0}=0.89,0.92\right.$ and 0.95$)$ (Fig. 9). The differences of \pm 0.03 in $\omega_{0}$, used in these simulations, correspond to the uncertainty of the single-scattering albedo inverted by AERONET.

According to Fig. 9, a variability of 0.03 in the estimate of the single-scattering albedo for the mean AOD observed over the Amazonia (0.2 to 0.4) would affect the 24h-DARF in about 1 to $2 \mathrm{~W} \mathrm{~m}^{-2}$. To evaluate if these values are consistent with the $24 \mathrm{~h}$-DARF variation observed by AERONET, the database was divided in AOD bins of 0.05 and the standard deviation of AERONET's 24h-DARF on each bin was analysed. This analysis showed that for AOD varying from 0.2 to 0.4 , the standard deviation of AERONET's 24h-DARF on each bin varied between 1.5 and $2.7 \mathrm{~W} \mathrm{~m}^{-2}$. This variation is higher than the one obtained using SBDART, because in those simulations, only single-scattering albedo was changed and other aerosol and atmospheric properties were fixed. However, there are other variables that influence the 24h-DARF observed by AERONET besides single-scattering albedo, such as scattering phase function, size distribution and atmospheric water vapour content. These values are very significant and they show that aerosol single-scattering albedo is a critical parameter to accurately assess DARF.

Considering all potential sources of uncertainties on aerosol and surface albedo models used in SBDART to compute the DARF, it is possible to consider the comparison shown in Fig. 8 as satisfactory. It is important to note that this validation consists of an indirect comparison, since, as previously discussed, it is not possible to obtain the flux at the TOA by direct methods. 


\section{Summary and conclusions}

This work has proposed a new methodology for assessing the direct radiative forcing of biomass burning aerosols over a large area of Amazonia using satellite remote sensing. Ten years of simultaneous CERES and MODIS retrievals, from 2000 to 2009, were used in this evaluation. An important correction (Patadia and Christopher, 2014) was applied to the DARF, to account for the anisotropic scattering of smoke aerosols.

The spatial and temporal distributions of the mean daily DARF were analysed. The analysis showed that due to the wind dynamics and fast transport of particles along the Amazon Basin, the spatial distribution of the DARF may considerably change even during short periods of time. The DARF varies strongly along the biomass burning season, showing up to $20 \mathrm{~W} \mathrm{~m}^{-2}$ daily variation. The intraseasonal behaviour of the DARF also varied significantly from year to year due to different burning intensity associated with different climatic conditions and other socio-economical changes (Davidson et al., 2012). We also observed that changes in cloud cover and satellite orbit track from one day to another can strongly influence daily DARF retrievals.

The average of DARF during the biomass burning season were computed and compared with DARF results obtained in a previous study (Sena et al., 2013). This comparison showed a mean difference of about $3 \mathrm{~W} \mathrm{~m}^{-2}$ on the DARF, depending on the methodology applied. This difference was mainly caused by two factors: (i) the difference in the reference used to represent the clean scene in these two methodologies, and (ii) the fact that, before 2005, CERES-SSF product contains properties of aerosols from an older MODIS collection (collection 4), which overestimates the forcing computed for those years when the previous methodology is applied.

An important part of our efforts focused on linking satellite remote sensing with ground-based aerosol and radiation flux measurements. The DARF evaluated using the new methodology proposed in this work was compared with AERONET and SBDART DARF assessments. The results obtained from those intercomparisons were very satisfactory. This comparison also indicates the importance of taking into account the angular distribution model corrections proposed by Patadia and Christopher (2014), and used in the present study. To our knowledge, this is the first time that satellite remote sensing assessments of the DARF have been compared with groundbased DARF estimates.

The new methodology introduced in this work provided a large-scale assessment of the direct radiative forcing of biomass burning aerosols over the Amazonia at higher temporal resolution than previous studies. It also showed an advantage over previous approaches for evaluating the DARF using satellite remote sensing, because it considerably reduces the statistical noise in the estimates of the DARF, resulting in a better correlation between DARF and AOD, compared to previous assessments. This new methodology could also be applied to assess the DARF in other places of the world under urban or biomass burning aerosol influences, if suitable and robust aerosol optical parameters are available.

Acknowledgements. The authors would like to thank the Atmospheric Science Data Center at the NASA Langley Research Center, for the processing and availability of CERES-SSF data. We thank Leandro Mariano and Otaviano Helene for the helpful discussions on uncertainties. We also thank FAPESP scholarships associated with the projects 2009/08442-7 and 2013/08582-9. This research was funded by the FAPESP projects 2008/58100-2, 2013/05014-0 and CNPq project 457843/2013-6 and 475735-2012-9. We thank Alcides C. Ribeiro, Ana L. Loureiro, Fábio de Oliveira Jorge and Simara Morais for technical support. We thank Brent Holben, Joel Schafer and Fernando Morais for support on long term AERONET operations in Amazonia.

Edited by: R. Krejci

\section{References}

Albrecht, B. A.: Aerosols, cloud microphysics, and fractional cloudiness, Science, 245, 1227-1230, 1989.

Andreae, M. O.: Aerosols before pollution, Science, 315, 50-51, 2007.

Andreae, M. O., Artaxo P., Fischer, H., Freitas, S. R., Grégoire, J. M., Hansel, A., Hoor, P., Kormann, R., Krejci, R., Lange, L., Lelieveld, J., Lindinger, W., Longo, K., Peters, W., de Reus, M., Scheeren, B., Dias, M., Strom, J., van Velthoven, P. F. J., and Williams, J.: Transport of biomass burning smoke to the upper troposphere by deep convection in the equatorial region, Geophys. Res. Lett., 28, 951-954, doi:10.1029/2000GL012391, 2001.

Andreae, M. O., Artaxo, P., Brandao, C., Carswell, F. E., Ciccioli, P., da Costa, A. L., Culf, A. D., Esteves, J. L., Gash, J. H. C., Grace, J., Kabat, P., Lelieveld, J., Malhi, Y., Manzi, A. O., Meixner, F. X., Nobre, A. D., Nobre, C., Ruivo, M., Silva-Dias, M. A., Stefani, P., Valentini, R., von Jouanne, J., and Waterloo, M. J.: Biogeochemical cycling of carbon, water, energy, trace gases, and aerosols in Amazonia: The LBA-EUSTACH experiments, J. Geophys. Res.-Atmos., 107, 8066, doi:10.1029/2001JD000524, 2002.

Andreae, M. O., Rosenfeld, D., Artaxo, P., Costa, A. A., Frank, G. P., Longo, K. M., and Silva-Dias, M. A. F.: Smoking rain clouds over the Amazon, Science, 303, 1337-1342, 2004.

Artaxo, P., Martins, J. V., Yamasoe, M. A., Procopio, A. S., Pauliquevis, T. M., Andreae, M. O., Guyon, P., Gatti, L. V., and Leal, A. M C.: Physical and chemical properties of aerosols in the wet and dry seasons in Rondonia, Amazonia, J. Geophys. Res.Atmos., 107, LBA49.1-LBA49.14, doi:10.1029/2001JD000666, 2002.

Artaxo, P., Rizzo, L. V., Paixao, M., de Lucca, S., Oliveira, P. H., Lara, L. L., Wiedemann, K. T., Andreae, M. O., Holben, B., Schafer, J., Correia, A. L., and Pauliquevis, T. M.: Aerosol particles in Amazonia: their composition, role in the radiation balance, cloud formation, and nutrient cycles, Geoph. Monog. Series, 186, 233-250, doi:10.1029/2008GM000778, 2009. 
Artaxo, P., Rizzo, L. V., Brito, J. F., Barbosa, H. M. J., Arana, A., Sena, E. T., Cirino, G. G., Bastos, W., Martin, S. T., and Andreae, M. O.: Atmospheric aerosols in Amazonia and land use change: from natural biogenic to biomass burning conditions, Faraday Discuss., 165, 203-235, doi:10.1039/C3FD00052D, 2013.

Betts, R. A., Malhi, Y., and Roberts, J. T.: The future of the Amazon: new perspectives from climate, ecosystem and social sciences, Philos. T. Roy. Soc. B, 363, 1729-1735, 2008.

Boucher, O., Randall, D., Artaxo, P., Bretherton, C., Feingold, G., Forster, P., Kerminen, V.-M., Kondo, Y., Liao, H., Lohmann, U., Rasch, P., Satheesh, S. K., Sherwood, S., Stevens, B., and Zhang, X. Y.: Clouds and Aerosols, in: Climate Change 2013: The Physical Science Basis. Contribution of Working Group I to the Fifth Assessment Report of the Intergovernmental Panel on Climate Change, edited by: Stocker, T. F., Qin, D., Plattner, G.-K., Tignor, M., Allen, S. K., Boschung, J., Nauels, A., Xia, Y., Bex, V., and Midgley, P. M., 571-657, Cambridge University Press, Cambridge, United Kingdom and New York, NY, USA, 2013.

Bowman, D. M. J. S., Balch, J. K., Artaxo, P., Bond, W. J., Carlson, J. M., Cochrane, M. A., D’Antonio, C. M., Defries, R. S., Doyle, J. C., Harrison, S. P., Johnston, F. H., Keeley, J. E., Krawchuk, M. A., Kull, C. A., Marston, J. B., Moritz, M. A., Prentice, I. C., Roos, C. I., Scott, A. C., Swetnam, T. W., van der Werf, G. R., and Pyne, S. J.: Fire in the Earth system, Science, 324, 481-484, doi:10.1126/science.1163886, 2009.

Charlson, R. J., Schwartz, S. E., Hales, J. M., Cess, R. D., Coakley, J. J., Hansen, J. E., and Hofmann, D. J.: Climate forcing by anthropogenic aerosols, Science, 255, 423-430, 1992.

Christopher, S. A.: Satellite remote sensing methods for estimating clear Sky shortwave Top of atmosphere fluxes used for aerosol studies over the global oceans, Remote Sens. Environ., 115, 3002-3006, 2011.

Chylek, P. and Wong, J.: Effect of absorbing aerosols on global radiation budget, Geophys. Res. Lett., 22, 929-931, 1995.

Coakley, J. A., Bernstein, R. L., and Durkee, P. A.: Effect of shipstack effluents on cloud reflectivity, Science, 237, 1020-1022, 1987.

Davidson, E. A. and Artaxo P.: Globally significant changes in biological processes of the Amazon Basin: Results of the Largescale Biosphere-Atmosphere Experiment, Glob. Change Biol., 10, 1-11, doi:10.1111/j.1529-8817.2003.00779.x, 2004.

Davidson, E. A., Araújo, A. C., Artaxo, P., Balch, J. K., Brown, I. F., Bustamante, M. M. C., Coe, M. T., DeFries, R. S., Keller, M., Longo, M., Munger, J. W., Schroeder, W., Soarez-Filho, B. S., Souza, C. M., and Wofsy, S. C.: The Amazon Basin in Transition, Nature, 481, 321-328, doi:10.1038/nature10717, 2012.

Dubovik, O. and King, M. D.: A flexible inversion algorithm for retrieval of aerosol optical properties from Sun and sky radiance measurements, J. Geophys. Res., 105, 20673-20696, doi:10.1029/2000JD900282, 2000.

Dubovik, O., Holben, B., Eck, T., Smirnov, A., Kaufman, Y., King, M., Tanré, D., and Slutsker, I.: Variability of absorption and optical properties of key aerosol types observed in worldwide locations, J. Atmos. Sci., 59, 590-608, 2002.

Dubuisson, P., Buriez, J. C., and Fouquart, Y.: High spectral resolution solar radiative transfer in absorbing and scattering media: Application to the satellite simulation, J. Quant. Spectrosc. Ra., 55, 103-126, 1996.
Echalar, F., Artaxo, P., Martins, J. V., Yamasoe, M., Gerab, F., Maenhaut, W., and Holben, B.: Long-term monitoring of atmospheric aerosols in the amazon basin: Source identification and apportionment, J. Geophys. Res., 103, 31849-31864, 1998.

Eck, T. F., Holben, B. N., Reid, J. S., O’Neill, N. T., Schafer, J. S., Dubovik, O., Smirnov, A., Yamasoe, M. A., and Artaxo, P.: High aerosol optical depth biomass burning events: a comparison of optical properties for different source regions, Geophys. Res. Lett., 30, 2035, doi:10.1029/2003GL017861, 2003.

Edwards, D. P., Emmons, L. K., Gille, J. C., Chu, A., Attié, J. L., Giglio, L., Wood, S. W., Haywood, J., Deeter, M. N., Massie, S T., Ziskin, D. C., and Drummond, J. R.: Satellite observed pollution from Southern Hemisphere biomass burning, J. Geophys. Res.-Atmos., 111, D14312, doi:10.1029/2005JD006655, 2006.

Feng, N. and Christopher, S. A.: Clear sky direct radiative effects of aerosols over Southeast Asia based on satellite observations and radiative transfer calculations, Remote Sens. Environ., 152, 333-344, 2014.

Freitas, S. R., Longo, K. M., Silva Dias, M. A. F., Silva Dias, P. L., Chatfield, R., Prins, E., Artaxo, P., and Recuero, F. S.: Monitoring the Transport of Biomass Burning Emissions in South America, Environ. Fluid Mech., 5, 135-167, doi:10.1007/s10652-0050243-7, 2005.

Freitas, S. R., Longo, K. M., Silva Dias, M. A. F., Chatfield, R., Silva Dias, P., Artaxo, P., Andreae, M. O., Grell, G., Rodrigues, L. F., Fazenda, A., and Panetta, J.: The Coupled Aerosol and Tracer Transport model to the Brazilian developments on the Regional Atmospheric Modeling System (CATT-BRAMS) - Part 1: Model description and evaluation, Atmos. Chem. Phys., 9, 28432861, doi:10.5194/acp-9-2843-2009, 2009.

Halthore, R., Eck, T., Holben, B., and Markham, B.: Sun photometric measurements of atmospheric water vapor column abundance in the 940-nm band, J. Geophys. Res., 102, 4343-4352, 1997.

Haywood, J. and Boucher, O.: Estimates of the direct and indirect radiative forcing due to tropospheric aerosols: A review, Rev. Geophys., 38, 513-543, doi:10.1029/1999RG000078, 2000.

Holben, B. N., Setzer, A., Eck, T. F., Pereira, A., and Slutsker, I.: Effect of dry-season biomass burning on Amazon basin aerosol concentrations and optical properties, 1992-1994, J. Geophys. Res.-Atmos., 101, 19465-19481, doi:10.1029/96jd01114, 1996.

Holben, B. N., Eck, T. F., Slutsker, I., Tanre, D., Buis, J. P., Setzer, A., Vermote, E., Reagan, J. A., Kaufman, Y. J., Nakajima, T., Lavenu, F., Jankowiak, I., and Smirnov, A.: AERONET - A Federated Instrument Network and Data Archive for Aerosol Characterization, Remote Sens. Environ., 66, 1-16, doi:10.1016/S0034-4257(98)00031-5, 1998.

King, M. D., Kaufman, Y. J., Menzel, W., and Tanre, D.: Remote sensing of cloud, aerosol, and water vapor properties from the Moderate Resolution Imaging Spectrometer (MODIS). IEEE T. Geosci. Remote, 30, 2-27, 1992.

Koren, I., Martins, J. V., Remer, L. A., and Afargan, H.: Smoke invigoration versus inhibition of clouds over the Amazon, Science, 321, 946-949, 2008.

Liou, K. N.: An introduction to atmospheric radiation, Vol. 84, Academic press, San Diego, California, 2002.

Loeb, N. G. and Su, W.: Direct aerosol radiative forcing uncertainty based on a radiative perturbation analysis, J. Climate, 23, 52885293, 2010. 
Loeb, N. G., Kato, S., Loukachine, K., and Manalo-Smith, N.: Angular Distribution Models for Top-of-Atmosphere Radiative Flux Estimation from the Clouds and the Earth's Radiant Energy System Instrument on the Terra Satellite. Part I: Methodology, J. Atmos. Ocean. Tech., 22, 338-351, doi:10.1175/JTECH1712.1, 2005.

Loeb, N. G., Kato, S., Loukachine, K., Manalo-Smith, N., and Doelling, D. R.: Angular Distribution Models for Top-ofAtmosphere Radiative Flux Estimation from the Clouds and the Earth's Radiant Energy System Instrument on the Terra Satellite. Part II: Validation, J. Atmos. Ocean. Tech., 24, 564-584, doi:10.1175/JTECH1983.1, 2007.

Longo, K., de Freitas, S. R., Andreae, M. O., Yokelson, R., and Artaxo, P.: Biomass Burning in Amazonia: Emissions, LongRange Transport of Smoke and Its Regional and Remote Impacts, in: Amazonia and Global Change, edited by: Keller, M., Bustamante, M., Gash, J., and Dias, P. S., American Geophysical Union, Geophysical Monograph 186, 209-234, ISBN: 978-087590-449-8, Washington, D.C., doi:10.1029/2008GM000778, 2009.

Lucht, W., Schaaf, C. B., and Strahler, A. H.: An algorithm for the retrieval of albedo from space using semiempirical BRDF models, IEEE T. Geosci. Remote, 38, 977-998, doi:10.1109/36.841980, 2000.

Malhi, Y., Roberts, J. T., Betts, R. A., Killeen, T. J., Li, W., and Nobre, C. A.: Climate change, deforestation, and the fate of the Amazon, Science, 319, 169-172, 2008.

Marengo, J. A., Nobre, C. A., Tomasella, J., Oyama, M. D., Oliveira, G. S., Oliveira, R., Camargo, H., Alves, L. M., and Brown, I. F.: The drought of Amazonia in 2005, J. Climate, 21, 495-516, 2008.

Martin, S. T., Andreae, M. O., Artaxo, P., Baumgardner, D., Chen, Q., Goldstein, A. H., Guenther, A. B., Heald, C. L., MayolBracero, O. L., McMurry, P. H., Pauliquevis, T., Pöschl, U., Prather, K. A., Roberts, G. C., Saleska, S. R., Silva Dias, M. A., Spracklen, D. V., Swietlicki, E., and Trebs, I.: Sources and Properties of Amazonian Aerosol Particles, Rev. Geophys., 48, RG2002, doi:10.1029/2008RG000280, 2010.

Mishra, A. K., Lehahn, Y., Rudich, Y., and Koren, I.: Co-variability of smoke and fire in the Amazon Basin, Atmos. Environ., 109, 97-104, doi:10.1016/j.atmosenv.2015.03.007, 2015.

Morton, D. C., Defries, R. S., Randerson, J. T., Giglio, L., Schroeder, W., and Van Der Werf, G. R.: Agricultural intensification increases deforestation fire activity in Amazonia, Glob. Change Biol., 14, 2262-2275, doi:10.1111/j.13652486.2008.01652.x, 2008.

Nobre, C. A., Mattos, L. F., Dereczynski, C. P., Tarasova, T. A., and Trosnikov, I. V.: Overview of atmospheric conditions during the Smoke, Clouds, and Radiation-Brazil (SCAR-B) field experiment, J. Geophys. Res.-Atmos., 103, 31809-31820, 1998.

Patadia, F. and Christopher, S. A.: Assessment of smoke shortwave radiative forcing using empirical angular distribution models, Remote Sens. Environ., 140, 233-240, 2014.

Patadia, F., Gupta, P., Christopher, S. A., and Reid, J. S.: A Multisensor satellite-based assessment of biomass burning aerosol radiative impact over Amazonia, J. Geophys. Res., 113, D12214, doi:10.1029/2007JD009486, 2008.
Patadia, F., Christopher, S. A., and Zhang, J.: Development of empirical angular distribution models for smoke aerosols: Methods, J. Geophys. Res.-Atmos., 116, 1984-2012, 2011.

Prins, E. M., Feltz, J. M., Menzel, W. P., and Ward, D. E.: An overview of goes- 8 diurnal fire and smoke results for scar-b and 1995 fire season in South America, J. Geophys. Res.-Atmos., 103, 31821-31835, 1998.

Procopio, A., Artaxo, P., Kaufman, Y., Remer, L., Schafer, J., and Holben, B.: Multiyear analysis of Amazonian biomass burning smoke radiative forcing of climate, Geophys. Res. Lett., 31, L03108-L03112, doi:10.1029/2003GL018646, 2004.

Remer, L. A., Kaufman, Y., Tanré, D., Mattoo, S., Chu, D. A., Martins, J. V., Li, R., Ichoku, C., Levy, R., Kleidman, R., Eck, T. F., Vermote, E., and Holben, B. N.: The MODIS aerosol algorithm, products and validation, J. Atmos. Sci., 62, 947-973, 2005.

Ricchiazzi, P., Yang, S., Gautier, C., and Sowle, D.: SBDART: A Research and Teaching Software Tool for Plane-Parallel Radiative Transfer in the Earth's Atmosphere, B. Am. Meteorol. Soc., 79, 2101-2114, 1998.

Ross, J., Hobbs, P., and Holben, B.: Radiative characteristics of regional hazes dominated by smoke from biomass burning in Brazil: Closure tests and direct radiative forcing, J. Geophys. Res., 103, 31925-31941, 1998.

Salomonson, V. V., Barnes, W., Maymon, P. W., Montgomery, H. E., and Ostrow, H.: MODIS: Advanced facility instrument for studies of the Earth as a system, IEEE T. Geosci. Remote, 27, 145-153, 1989.

Satyamurty, P., da Costa, C. P. W., and Manzi, A. O.: Moisture source for the Amazon Basin: a study of contrasting years, Theor. Appl. Climatol., 111, 195-209, 2013.

Schaaf, C. B., Gao, F., Strahler, A. H., Lucht, W., Li, X., Tsang, T., Strugnell, N. C., Zhang, X., Jin, Y., Muller, J.-P., Lewis, P., Barnsley, M., Hobson, P., Disney, M., Dunderdale, M., Doll, C., d'Entremont, R. P., Hu, B., Liang, S., Privette, J. L., and Roy, D.: First operational BRDF, albedo nadir reflectance products from MODIS, Remote Sens. Environ., 83, 135-148, doi:10.1016/S0034-4257(02)00091-3, 2002.

Schafer, J. S., Eck, T. F., Holben, B. N., Artaxo, P., and Duarte, A.: Characterization of the optical properties of atmospheric aerosols in Amazonia from long term AERONET monitoring (1993-1995; 1999-2006), J. Geophys. Res.-Atmos., 113, D04204, doi:10.1029/2007JD009319, 2008.

Sena, E. T., Artaxo, P., and Correia, A. L.: Spatial variability of the direct radiative forcing of biomass burning aerosols and the effects of land use change in Amazonia, Atmos. Chem. Phys., 13, 1261-1275, doi:10.5194/acp-13-1261-2013, 2013.

Smith, G. L.: Effects of time response on the point spread function of a scanning radiometer, Appl. Optics, 33, 7031-7037, 1994.

Stamnes, K., Tsay, S., Wiscombe, W., and Jayaweera, K.: Numerically stable algorithm for discrete-ordinate-method radiative transfer in multiple scattering and emitting layered media, Appl. Optics, 27, 2502-2509, 1988.

Sundström, A.-M., Arola, A., Kolmonen, P., Xue, Y., de Leeuw, G., and Kulmala, M.: On the use of a satellite remote-sensingbased approach for determining aerosol direct radiative effect over land: a case study over China, Atmos. Chem. Phys., 15, 505-518, doi:10.5194/acp-15-505-2015, 2015. 
Ten Hoeve, J. E., Remer, L. A., Correia, A. L., and Jacobson, M. Z.: Recent shift from forest to savanna burning in the Amazon Basin observed by satellite, Environ. Res. Lett., 7, 024020, doi:10.1088/1748-9326/7/2/024020, 2012.

Twomey, S.: The influence of pollution on the shortwave albedo of clouds, J. Atmos. Sci., 34, 1149-1152, 1977.

Wielicki, B. A., Barkstrom, B. R., Harrison, E. F., Lee, R. B., Smith, G. L., and Cooper, J. E.: Clouds and the Earth's Radiant Energy System (CERES): An Earth observing system experiment, B. Am. Meteorol. Soc., 77, 853-868, 1996.
Yu, H., Kaufman, Y. J., Chin, M., Feingold, G., Remer, L. A., Anderson, T. L., Balkanski, Y., Bellouin, N., Boucher, O., Christopher, S., DeCola, P., Kahn, R., Koch, D., Loeb, N., Reddy, M. S., Schulz, M., Takemura, T., and Zhou, M.: A review of measurement-based assessments of the aerosol direct radiative effect and forcing, Atmos. Chem. Phys., 6, 613-666, doi:10.5194/acp-6-613-2006, 2006.

Zhang, J., Christopher, S. A., Remer, L., and Kaufman, Y. J.: Shortwave aerosol radiative forcing over cloud-free oceans from Terra: 2. Seasonal and global distributions, J. Geophys. Res., 110, D10S24, doi:10.1029/2004JD005009, 2005. 